\title{
Characterization of a third simple tandem repeat polymorphism in the human glucokinase gene
}

\author{
M.Stoffel and G.I.Bell \\ Howard Hughes Medical Institute, and Departments of Biochemistry and Molecular Biology, and Medicine, University of Chicago, \\ Chicago, Illinois, USA
}

\begin{abstract}
Summary. Recent studies have implicated mutations in the glucokinase gene as a cause of early-onset Type 2 (non-insulin-dependent) diabetes mellitus. Two simple tandem repeat DNA polymorphisms have been identified in this gene and used for genetic studies. However, their heterozygosity is relatively low and not all families are informative for linkage
\end{abstract}

with these markers. Here we report the characterization of a third simple tandem repeat polymorphism that can be used for genetic studies.

Key words: DNA polymorphism, genetics, chromosome 7 .
Recent genetic studies of families with early-onset Type 2 (non-insulin-dependent) diabetes mellitus or maturityonset diabetes of the young (MODY) have localized diabetes-susceptibility genes to human chromosomes 7 and 20 [1-3]. Although the identity of the gene on chromosome 20 has not been determined, we have recently shown that mutations in the glucokinase gene on chromosome 7 are the cause of early-onset Type 2 diabetes in four French and one British family [4-6].

Two simple tandem repeat DNA polymorphism (STRPs) in the glucokinase gene have been described $[7,8]$. One, designated as GCK1, is located $\approx 8.0$ kilobases $(\mathrm{kb})$ downstream of exon 10 [7] and the second, GCK2, is $\approx 6.0 \mathrm{~kb}$ upstream of exon $1 \mathrm{a}$, the beta-cell specific exon 1 [8]. However, the heterozygosity of both GCK1 and GCK2 is relatively low and as a consequence there are often families in which either or both of these markers is not fully informative for linkage studies. Here, we report the characterization of a third STRP that we have found useful in genetic studies of diabetes.

\section{Materials and methods}

\section{Identification of a microsatellite DNA polymorphism}

A $10 \mathrm{~kb}$ EcoRI fragment from the human glucokinase genomic clone $\lambda$ hGK-7 [5] was digested with Sau3AI and subcloned into the BamHI site of M13mp18. Clones containing CA dinucleotide repeats were identified by hybridization with nick-translated ${ }^{32} \mathrm{P}-\mathrm{la}-$ belled poly(dA-dC)-poly (dG-dT) (Pharmacia LKB Biotechnology, Piscataway, NJ) and sequenced [8].

\section{Amplification of the microsatellite DNA polymorphism}

Two primers (hGK3-1, 5'-GGTTATGTAGCATCAGGATG-3', and hGK3-4, 5'-TCTCTCTGTCTCTGTGAGTC-3'), were used to amplify an $\approx 274$ base pair (bp) CA-GA repeat-rich region. The polymerase chain reaction (PCR) was performed using ${ }^{32} \mathrm{P}$-labelled hGK3-1 and unlabelled hGK3-4. DNA was denatured at $94^{\circ} \mathrm{C}$ for $5 \mathrm{~min}$, followed by 30 cycles of denaturation at $94^{\circ} \mathrm{C}$ for $1 \mathrm{~min}$, annealing at $60^{\circ} \mathrm{C}$ for $1 \mathrm{~min}$, extension at $72^{\circ} \mathrm{C}$ for $2 \mathrm{~min}$ and a final extension step of $10 \mathrm{~min}$. The PCR products were analysed on a $5 \%$ denaturing polyacrylamide gel. The PCR reactions were carried out in a volume of $25 \mu \mathrm{l}$ containing $50 \mathrm{mmol} / \mathrm{h} \mathrm{KCl}, 10 \mathrm{mmol} / \mathrm{l}$ Tris-HCI $\mathrm{pH} 8.3,1.5 \mathrm{mmol} / \mathrm{l} \mathrm{MgCl}, 200 \mu \mathrm{mol} / \mathrm{l}$ each of dATP, dCTP, dGTP, dTTP, $0.1 \mu \mathrm{g}$ of DNA, 10 pmol of each primer and 1.5 units of Taq polymerase (Perkin Elmer Cetus, Norwalk, Conn., USA) in a GeneAmp 9600 PCR System (Perkin Elmer Cetus).

\section{Results}

An imperfect compound STRP consisting of a series of $\mathrm{CA}$ and GA repeats was identified in the glucokinase gene (Fig. $1 \mathrm{~A}) \approx 4.3 \mathrm{~kb}$ upstream of exon $1 \mathrm{a}$. This STRP was polymorphic and five alleles were seen in Caucasians and African-Americans (Fig. 1B, Table 1); only three alleles were noted in sample of 20 Asians. The heterozygosity varied from 0.55 in Caucasian and Asians to 0.66 in African-Americans. Co-dominant inheritance was observed in three multi-generation Caucasian pedigrees. 

hGK3-1

GGTTCACGGTTATGTAGCATCAGGATGGGGCTCCCTCTTTGCTCAGGCCAGCAAAAGAGAGACAGAAAGAGAGAGAGAGA CCAAGTGCCAATACATCGTAGTCCTACCCCGAGGGAGAAACGAGTCCGGTCGTTTTCTCTCTGTCTTTCTCTCTCTCTCT

TTGAGAGAGTGAGAAAAACAGATATCACACACACACACACAGAAAAAGAAACAAAGCGAAATACAGAAAGATAGACACAG AACTCTCTCACTCTTTTTGTCTATAGTGTGTGTGTGTGTGTCTTTTTCTTTGTTTCGCTTTATGTCTTTCTATCTGTGTC

AGAGAGAGTGAGAAAAACAGATACACACACACACACACACAGAGAAAAAGAAACAAAGCGAAAGACAGAAAGGTAGACAC TCTCTCTCACTCTTTTTGTCTATGTGTGTGTGTGTGTGTGTCTCTTTTTCTTTGTTTCGCTITCTGTCTTTCCATCTGTG

AGAGAGAGAGAGAGACAGACTCACAGAGACAGAGAGAATACTACAGACAGACACACAGAGAGACAATGAGACAGAGAGAG TCTCTCTCTCTCTCTGTCTGAGTGTCTCTGTCTCTCTTATGATGTCTGTCTGTGTGTCTCTCTGTTACTCTGTCTCTCTC hGK3-4

AGGGGGAGAAAGAGACAGAAAGAGAGAGATACAGAGAAGTTCACACAGCTGTGAGGGGGCTAAAGGAGGAAGTGT 475 TCCCCCTCTTTCTCTGTCTTTCTCTCTCTATGTCTCTTCAAGTGTGTCGACACTCCCCCGATTTCCTCCTTCACA

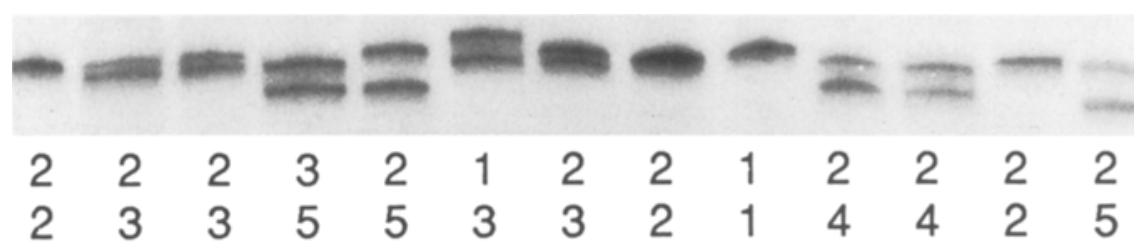

B

\section{Genotype}

Fig. 1A, B. Sequence and amplification of a simple tandem repeat DNA polymorphism, GCK3. A The nucleotide sequence of the region of GCK 3 is shown. The sequences of the nucleotide primers used to amplify this region are shown in bold-face type. B PCR amplification of GCK3. The genotypes of the unrelated individuals studied here are shown at the bottom of the figure
Table 1. Characterization of simple tandem repeat DNA polymorphism, GCK3

\begin{tabular}{|c|c|c|c|c|}
\hline \multicolumn{2}{|c|}{ Allele frequencies } & \multicolumn{3}{|c|}{ Racial group } \\
\hline$\overline{\text { Allele }}$ & $\begin{array}{l}\text { Size } \\
\text { (base pairs) }\end{array}$ & $\begin{array}{l}\text { Caucasian } \\
(n=28)\end{array}$ & $\begin{array}{l}\text { African- } \\
\text { American } \\
(n=15)\end{array}$ & $\begin{array}{l}\text { Chinese } \\
(n=20)\end{array}$ \\
\hline 1 & 276 & 0.058 & 0.033 & - \\
\hline 2 & 274 & 0.588 & 0.567 & 0.60 \\
\hline 3 & 272 & 0.304 & 0.233 & 0.275 \\
\hline 4 & 270 & 0.036 & 0.10 & - \\
\hline 5 & 268 & 0.018 & 0.067 & 0.125 \\
\hline \multicolumn{2}{|c|}{ Heterozygosity } & 0.55 & 0.66 & 0.55 \\
\hline
\end{tabular}

\section{Discussion}

We have identified a third STRP, termed GCK3, in the glucokinase gene which will be useful for linkage studies of this locus in Type 2 diabetes. The heterozygosity of GCK3 is higher than GCK1 and similar to that previously noted for GCK2. Since PCR typing of STRPs is very rapid, it is worthwhile first step for selecting those families which should be studied further for glucokinase mutations. The identification of a third STRP in the glucokinase gene will be valuable in this regard.

Acknowledgements. These studies were supported by the Howard Hughes Medical Institute and NIH Grant DK-20595. M.S. was supported by a fellowship of the Deutsche Forschungsgemeinschaft. The nucleotide sequence reported in this paper has been deposited in the GenBank data base (accession no. L05145).

\section{References}

1. Froguel Ph, Vaxillaire M, Sun F et al. (1992) Close linkage of glucokinase locus on chromosome $7 p$ to early-onset non-insulin-dependent diabetes mellitus. Nature 356: 162-164

2. Hattersley AT, Turner RC, Permutt MA et al. (1992) Linkage of type 2 diabetes to the glucokinase gene. Lancet 339: 1308-1310

3. Bell GI, Yiang K-S, Newman MV et al. (1991) Gene for non-insulin-dependent diabetes mellitus (maturity-onset diabetes of the young subtype) is linked to DNA polymorphism on human chromosome 20q. Proc Natl Acad Sci USA 88: 1484-1488

4. Vionnet N, Stoffel M, Takeda J et al. (1992) Nonsense mutation in the glucokinase gene causes early-onset non-insulin-dependent diabetes mellitus. Nature 356: 721-722

5. Stoffel M, Froguel Ph, Takeda J et al. (1992) Human glucokinase gene: isolation characterization, and identification of two missense mutations linked to early-onset non-insulin-dependent (type 2) diabetes mellitus. Proc Natl Acad Sci USA 89: 7698-7702

6. Stoffel M, Patel P, Lo Y-MD et al. (1992) Characterization of a missense glucokinase mutation in maturity-onset diabetes of the young and mutation screening in late-onset diabetes. Nature Genetics 2: 153-156

7. Matsutani A, Janssen R, Donis-Keller H, Permutt MA (1992) A polymorphic $(\mathrm{CA})_{\mathrm{n}}$ repeat element maps the human glucokinase gene (GCK) to chromosome 7p. Genomics 12: 319-325

8. Nishi S, Stoffel M, Xiang K, Shows TB, Bell GI, Takeda J (1992) Human pancreatic beta-cell glucokinase: cDNA sequence and localization of the polymorphic gene to chromosome 7, band p13. Diabetologia 35: 743-747

Received: 7 September 1992

Dr. G. Bell

Howard Hughes Medical Institute, University of Chicago

5841 S.Maryland Ave., MC1028

Chicago, IL 60637

USA 